\title{
The Current Situation of E-Commerce Development of Agricultural Products in Fujian and Its Countermeasures
}

\author{
Jingxian $\mathrm{Xu}$ \\ TSL School of Business and Information Technology \\ Quanzhou Normal University \\ Quanzhou, China \\ yjsxjx@126.com
}

\author{
Jianhong Guo* \\ TSL School of Business and Information Technology \\ Quanzhou Normal University \\ Quanzhou, China \\ jianhongguo@126.com
}

\begin{abstract}
E-commerce of agricultural products can reduce logistics costs, increase farmers' income, and enable large-scale production of agriculture. Therefore, the study of e-commerce of agricultural products is very meaningful. In addition to agricultural products, e-commerce in Fujian has developed very well. However, the development of e-commerce for agricultural products very slow, therefore, it is necessary to study the factors restricting the e-commerce of agricultural products in Fujian. The purpose of this research project is to find out the factors that restrict the development of e-commerce of agricultural products in Fujian, and formulate development strategies according to these constraints. In this study, a large amount of literature was consulted, and through the network to find the relevant agricultural e-commerce data, summarizes the development status of Fujian agricultural products e-commerce, and summarizes the existing problems of e-commerce of agricultural products, our conclusion is: the level of awareness of farmers of e-commerce of agricultural products is low, standardization construction lags behind, rural logistics system is imperfect, and rural informatization foundation is weak. Our research shows that the Fujian provincial government and enterprises adopt some corresponding strategies will break through the bottleneck of development.
\end{abstract}

Keywords-E-commerce; agricultural product; development; countermeasure

\section{INTRODUCTION}

With the development of society and the change of people's consumption concept, agricultural products are confronted with more challenge, so the agricultural products must respond to the demand of the market quickly, but because of the problems such as perishable, high circulation cost and asymmetric information, the agricultural products are often unsalable. With e-commerce platform can make agricultural products to achieve sales, the original agricultural products generally go through multi dealer system, now producers and consumers can communicate directly, save a lot of time, and reduce the cost of distribution of agricultural products, fundamentally solve the contradiction between production and sales, online transactions to reflect market supply and demand, thus can guide farmers to arrange production scientifically, so as to realize the accurate production of agricultural products. Fujian province has rich agricultural products resources, and most of the sales of agricultural products still use the traditional way, especially in rural areas. The trading mode of farmers' markets is backward and can not meet the diversified needs of consumers. Therefore, the development of e-commerce of agricultural products is conducive to improve the efficiency of agricultural products sales in Fujian and increase the income of farmers. It is of great significance to promote the development of agricultural products in Fujian province.

\section{DEVELOPMENT STATUS OF E-COMMERCE OF AGRICULTURAL PRODUCTS IN FUJIAN PROVINCE}

Under the impetus of the e-commerce strategy of Fujian provincial government, the electronic commerce of agricultural products in Fujian province has developed rapidly. According to statistics, the e-commerce application rate of agricultural products in Fujian is above $50 \%$, and the sales revenue achieved by e-commerce accounts for more than $8 \%$ of the total sales revenue. At present, Fujian has established many agricultural related websites, such as Fujian agricultural information network and other websites. They provide price and demand for these sites for electronic trading of agricultural products; agricultural products e-commerce enterprises are increasingly committed to online product sales, they commissioned by the third party trading platform sales of agricultural products [1]. At present, the level of e-commerce application of agricultural products in Fujian ranks first in the country, and e-commerce has become an important channel for expanding sales revenue of agricultural products in Fujian province.

Since 2012, the development of e-commerce in Fujian province is in good condition, and the annual turnover is increasing year by year, as shown in Figure 1 (data source: Fujian Provincial Bureau of statistics and Fujian Provincial Department of Commerce). According to relevant departments statistics, in 2015, Fujian e-commerce transactions amounted to 711 billion 600 million yuan, an increase of $42.6 \%$. The number of national e-commerce demonstration base in Fujian ranks fourth in the country, the e-commerce development index ranks third; with 4 national e-commerce model city, 5 
national e-commerce demonstration base, 7 national ecommerce demonstration enterprises, 10 national e-commerce demonstration county rural comprehensive [2].

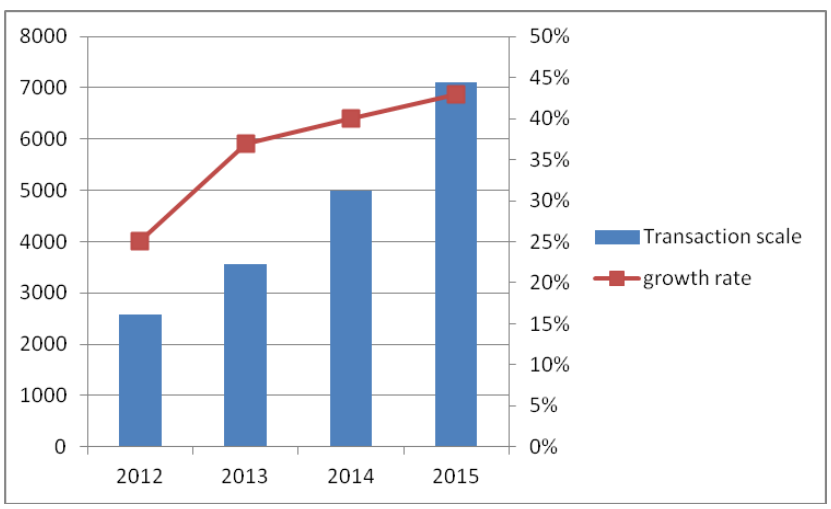

Fig. 1. The scale of Fujian Province E-commerce transactions

In addition, the rapid development of e-commerce in cities in Fujian province in 2015 is shown in Table 1 (source: Statistics Bureau of Fujian province). Data from the table show that in all cities in Fujian, e-commerce transactions are increasing rapidly. And the growth rate of each city is more than $30 \%$, of which $95.2 \%$ is Longyan, Nanping is the $79.6 \%$, Zhangzhou is $75 \%$, and Ningde $33.3 \%$ is the lowest [3].

TABLE I THE E - COMMERCE TRANSACTIONS OF ALL CITIES IN FUJIAN PROVINCE

\begin{tabular}{|l|l|l|l|}
\hline \multicolumn{1}{|c|}{ City } & $\begin{array}{c}\text { E-commerce } \\
\text { Transaction } \\
\text { Volume(billion } \\
\text { yuan) }\end{array}$ & Growth Rate(\%) & $\begin{array}{c}\text { Proportion of } \\
\text { the Whole } \\
\text { Province (\%) }\end{array}$ \\
\hline Quanzhou & 2021 & 45.2 & 28.4 \\
\hline Xiamen & 1914 & 34.6 & 26.9 \\
\hline Fuzhou & 1146 & 34.3 & 16.1 \\
\hline Putian & 676 & 45.7 & 9.5 \\
\hline Zhangzhou & 384 & 75.0 & 5.4 \\
\hline Ningde & 306 & 33.3 & 4.3 \\
\hline Sanming & 249 & 38.5 & 3.5 \\
\hline Nanping & 235 & 79.6 & 3.3 \\
\hline
\end{tabular}

\section{PROBlems EXISTING IN E-COMMERCE OF AGRICULTURAL PRODUCTS IN FUJIAN PROVINCE}

On the whole, the electronic commerce of agricultural products in Fujian has made great progress, but there are still many problems The main problems are as follows:.

\section{A. Farmers Have a low Level of Understanding Of E- commerce}

The rural areas of Fujian province do not attach importance to education, makes a lot of farmers' education level is relatively low, the lack of e-commerce knowledge, which led directly to the farmers for e-commerce and lack a correct understanding and thus do not understand the benefits of electronic commerce [4]. However, in the information age, mastering information will be in a favorable competitive position, and outdated ideas will be eliminated by the market. Therefore, we must improve the level of education in rural areas, support rural youth to carry out e-commerce, carry out online shop training, in order to improve the ability to use ecommerce in rural areas and establish new concepts of online marketing.

\section{B. The standardization of agricultural products lags behind}

The agricultural product standardization system including quality standard system and quality inspection system and quality certification of agricultural products, the agriculture of Fujian Province in the system construction is not perfect, is not conducive to the application of e-commerce of agricultural products.

\section{The construction of rural logistics system is imperfect}

At present, the Fujian provincial express network has basically achieved full coverage at the county level, but the coverage rate at the township level is not high. Table 2 is the Fujian Logistics Association statistics at all levels of fixed observation points, from the table can be seen at the village level logistics coverage rate worst, see Table 2 for details.

TABLE II THE NUMBER OF FIXED OBSERVATION POINTS IN DIFFERENT DELIVERY RANGES

\begin{tabular}{|l|l|}
\hline \multicolumn{1}{|c|}{ Express delivery range } & $\begin{array}{c}\text { Number of fixed observation point } \\
\text { villages (units) }\end{array}$ \\
\hline County-level & 43 \\
\hline Town / Township & 25 \\
\hline village & 2 \\
\hline
\end{tabular}

\section{The foundation of rural informatization is weak}

To carry out rural e-commerce, network infrastructure and communication tools are essential. Most of the rural areas in Fujian are relatively backward in information construction, network infrastructure is not perfect, and network coverage is very low. These have prevented farmers from getting information about agricultural products through the Internet, and the proportion of Internet users involved in agriculture is only $1 \%$, according to the profession of Internet users, and the number of farmers accessing the Internet is very little. Although the website of agricultural product information increases gradually, but the website provides the information not to be comprehensive, the information lags behind, lacks specialized..

\section{COUNTERMEASURES OF DEVELOPING E-COMMERCE OF AGRICULTURAL PRODUCTS IN FUJIAN PROVINCE}

\section{A. The government should create a favorable environment for the development of e-commerce}

The government through the cultivation of professional talents, and the promulgation of relevant policies to create favorable conditions for the development of e-commerce development, and promote the development of e-commerce of agricultural products in August 2015, the Fujian Provincial People's government issued "to promote the development of rural e-commerce action plan" regulations [5], it makes agricultural products e-commerce has made many breakthroughs, and it provides many agricultural e-commerce system, such as constructing rural e-commerce industry development platform, construction of agricultural product 
network marketing system, service system construction and improvement of rural rural e-commerce e-commerce logistics distribution system.

\section{B. Strengthening standardization and brand building of agricultural products}

Standardized products are easier to implement e-commerce. The government should strengthen the quality standard system of agricultural products, the quality inspection system and the construction of the quality certification system for agricultural products [6]. We should speed up the formulation of grading, grading, packaging and Transportation Standards for agricultural products that meet the needs of e-commerce. Local governments at all levels should focus on the development of quality standards for special agricultural products in this region, and entrust leading enterprises to formulate quality standards for related agricultural products [7]. Brand agricultural products are easy to sell on the internet. The government should pay attention to guide the brand building of agricultural products, encourage producers of characteristic agricultural products to declare agricultural products trademarks, and comprehensively upgrade the grades of agricultural products. Establish quality control system to ensure the quality of agricultural products. From the procurement of goods, we need strict quality supervision.

\section{Speed up the construction of agricultural products logistics system}

In addition to the implementation of e-commerce network trading platform, but also need the support of logistics, on the one hand to improve the logistics infrastructure, accelerate the construction of traffic network, which can ensure the quality of agricultural products and reduce the cost of the circulation of agricultural products; on the other hand, open up Township transportation logistics lines, make full use of the existing rural commodity circulation service system and play the service function of township business center, to build urban and rural logistics platform, encourage logistics enterprises to establish outlets in rural areas, improve the rural logistics network coverage. Rational planning and construction of the entire cold chain logistics infrastructure, and vigorously develop fresh agricultural cold chain logistics, providing efficient logistics services for fresh agricultural products.

\section{We should strengthen the informatization of agricultural products and perfect the information system of agricultural products}

Speed up the construction of rural informatization, lay the foundation for agricultural products online transactions, and provide information services for agricultural products logistics and distribution. At present, the majority of Fujian province rural area network has been opened, the formation of agricultural information service in Fujian Province agricultural information network as a leader, but the network extends to the village the ratio is relatively low, resulting in the transmission of information "fracture", therefore, to strengthen the construction of agricultural information network; on the other hand, the government to make the information collection and release the demand for agricultural products, promote agricultural products supply and demand sides of the exchange of information. At the same time, the government should formulate a policy of encouraging the Internet of things technology, encourage logistics enterprises to use Internet of things technology, and gradually establish a logistics system of agricultural products, in order to promote the efficient circulation of agricultural products.

\section{SUMMARY}

The development of e-commerce of agricultural products a trend which cannot be halted, it to the development of agricultural products has many benefits, but because of Agricultural Perishable, not easy to transport, not easy to store; farmers' level of e-commerce knowledge is very low and the logistics distribution system is not perfect, so the development of Fujian agricultural products e-commerce also need to make a lot of effort. However, it is of great significance to deeply understand these problems and take corresponding measures to solve these problems so that farmers can increase their income and promote the development of e-commerce of agricultural products in Fujian province.

\section{ACKNOWLEDGMENT}

This work was financially supported by:

1) Fujian Natural Science Foundation of China(Number 2015J01286):Research on e-commerce chain based on Collaborative Perspective in cloud computing environment.

2) JK project of Fujian Provincial Department of Education(Number JK2014037):Research on e-commerce chain coordination based on Cloud Computing.

3) Curriculum Construction Project of Quanzhou Normal University: Demonstration Network Course Construction--ERP (Enterprise resource planning).

4) Students Innovation and Entrepreneurship Training Program Funded Projects of Quanzhou Normal University.

\section{REFERENCES}

[1] Lingcheng Chen, and Peifen Zhuang, Current Situation and Countermeasures of Agricultural Products E - commerce in Fuzhou City, Exploration of agriculture in Taiwan, 2017, pp. 86-90 (In Chinese).

[2] Xiaofeng Luo, Innovation and Development of E - commerce Model of Agricultural Products in Fujian Province, Journal of Sanming University, 2013, pp. 35-39(In Chinese).

[3] Bizhen Qiu, Analysis and Countermeasure of Agricultural Electronic Commerce Development in Fujian Province, Agriculture outlook, 2014, pp. 50-53(In Chinese).

[4] Penglin Yu, Analysis of the development of e-commerce of agricultural products in Fujian Province, Human resource management, 2015, pp. 60-61(In Chinese).

[5] Shundan Zhong,Hejun Lin, Current Situation and Countermeasure of Agricultural Products E - commerce in Fujian Province,Taiwan Agriculture Exploration, 2015, pp.43-47(In Chinese).

[6] Yeming Zeng, and Yan Sheng, Review of e-commerce research on fresh agricultural products, journal of anhui agricultural sciences, 2015 ,pp. 341-343(In Chinese).

[7] Zhongyan Lin, Dachuan Zheng, and Chenhua Zhang, Research Report on the development of e-commerce in Fujian Province in 2015, strait science, 2016 ,pp. 146-155(In Chinese). 